\title{
Analysis of a Railway Vehicle with Unevenness on Wheel
}

Mária Loulová, Andrej Suchánek, Jozef Harušinec, Peter Strážovec

Faculty of Mechanical Engineering, University of Zilina, Univerzitná 8215/1, 01026 Žilina. Slovak Republic. E-mail: maria.loulova@fstroj.uniza.sk, andrej.suchanek@fstroj.uniza.sk, jozef.harusinec@fstroj.uniza.sk, peter.strazovec@fstroj.uniza.sk.

One of the basic principles of railway vehicles is their carrying and guiding. In the contact pair of a wheel and a rail, one body is rolled on the surface of the other part and all main forces are transmitted in this contact. Contact between wheel and rail is also important from an economic aspect as it is related to the wear of the track rails and the wheel thread itself, including the wheel flange, and has caused the necessary maintenance of the track and the vehicles themselves. Therefore, our article focuses on simulating the influence of a flat wheel on changes in wheel forces. The model was created in the CATIA program and was consequently imported into the SIMPACK program, which was followed by analysis of the passage of the vehicle along the track. In the simulation, we considered an ideal track and a wheel flat on the right front wheel. We also plan to work with these results by adding and comparing them with results obtained by applying irregularity to our ideal track.

Keywords: Wheel flat, simulation, rail - wheel contact, safety against derailment.

\section{Introduction}

In the wheel-rail contact pair, one body is being rolled over the surface of the second body $[8,10,11,13]$. The issue of wheel-rail contact is also addressed in other professional publications $[9,12,15,17,19,20,24]$. If the contact surfaces are sufficiently smooth, there is no vibration and consequent negative effects (noise generation, increased forces in wheel-rail contact) [21, 22]. In Fig. 1, there is a picture of a wheel damaged by the formation of wheel flat on the wheel tread.

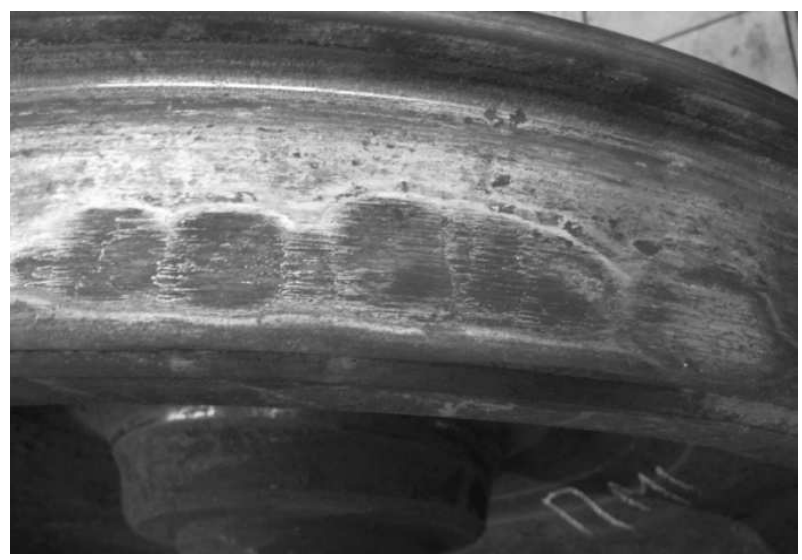

Fig. 1 Wheel with a wheel flat

The wheel is the second part of the contact pair and its unevenness can be defined as the deviations of the circularity (differences between an actual radius of the wheel and an ideal nominal radius) [4, 6]. Non-circularity can be evaluated in the plane of the touch circles $(70 \mathrm{~mm}$ from the inner face of the wheel) or in planes parallel therewith. Numerical processing of measured data is necessary to perform the analysis. The basis for evaluating wheel non- circularity is to know the instantaneous radius values of the wheel, depending on the angle of rotation of the wheel $[14,16,23]$.

Measurement of circular deviations can be performed by several methods $[7,18]$. Circularity is most often controlled by special touch devices where a measuring contact rotates around a fixed component or inversely, the component rotates around the rotary axis and the deviations are continuously scanned by the deviation meter.

\section{Simulation conditions}

For the needs of the simulation, a model of a tilting bogie and car body of the rail vehicle was created in CATIA V5R20 program and imported into SIMPACK 9.9 program afterwards. It was necessary to define joints between indivi-dual parts using force elements in SIMPACK and set the characteristics of springs and dampers using input parameters. Important was also to define two hydraulic cylinders that cause the upper tilting bolster to tilt and therefore also the tilting of the car body in curve. The model uses an active system of tilting comparable to the Pendolino train. In our simulation however, the tilting mechanism was turned off. The created model can be seen in Fig. 2.

The vehicle ran along a track with the length of $6 \mathrm{~km}$, composed of 4 curves with a radius of $600 \mathrm{~m}$ (Fig.2). The superelevation of the track was set to $150 \mathrm{~mm}$. Wheel profile S 1002 with a nominal radius of $445 \mathrm{~mm}$ and rail profile defined by the S91700_16 geometry were set for the track model.

In order to simulate the rail vehicle running and evaluate ride properties of motion smoothing of rail vehicles by means of computer simulation, program Simpack 2014 has been used. This software allows to create subsystems of rail vehicles, whole rail vehicles and trains. 


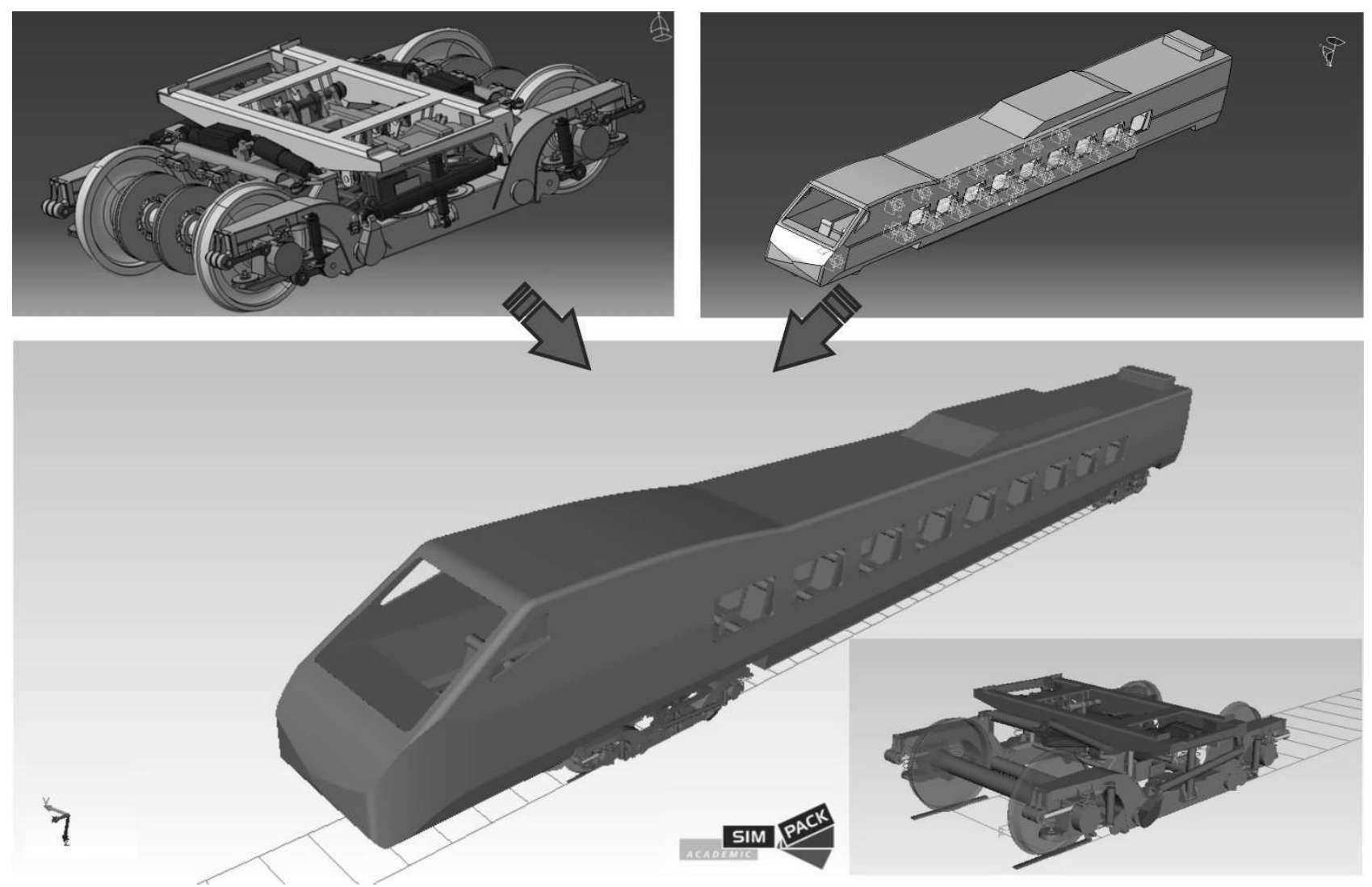

Fig. 2 Model of bogie and body vehicle in program Simpack imported into program CATIA

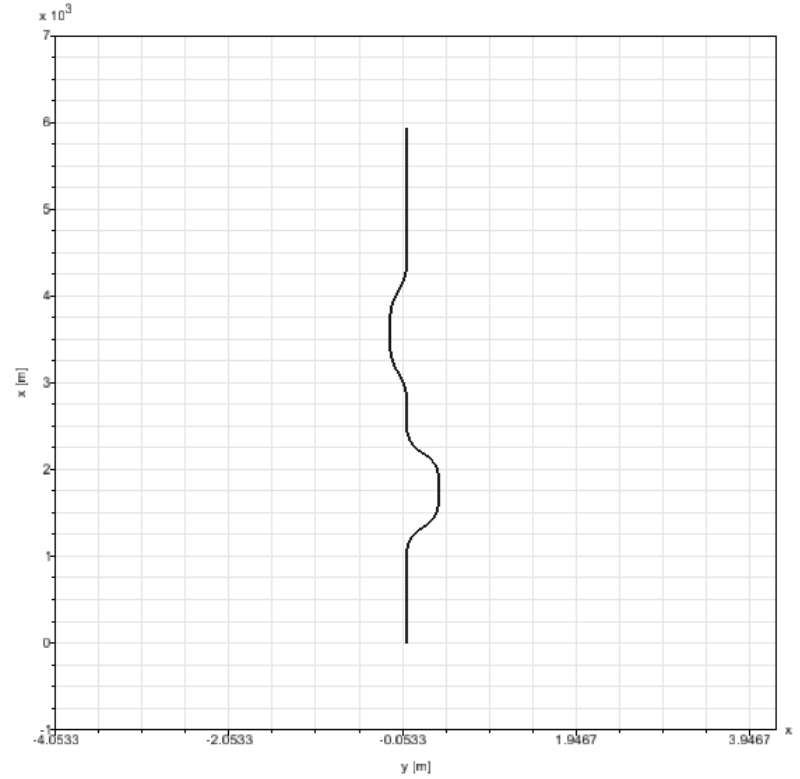

Fig. 3 Geometry of the track model

Wheel untrueness causes force changes in wheel-rail contact. If untrueness is created on a wheel, the nominal wheel radius is not constant anymore, but varies with the wheel rotation angle. In program Simpack, it is possible to specify the wheel untrueness in three different ways: radius deviations, Fourier coefficients and harmonic function (simple polygonality) (Fig. 4). We used radius deviation (Fig. 5) for our simulation, with parameters defined in Tab.1.
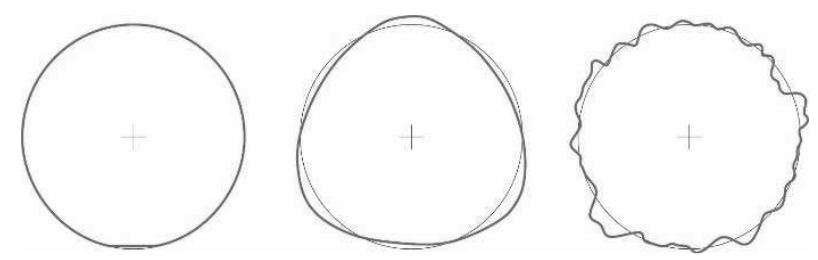

Fig. 4 Typical untrue wheels: wheel flat (left), 'triangle' (center), arbitrary shape (right)

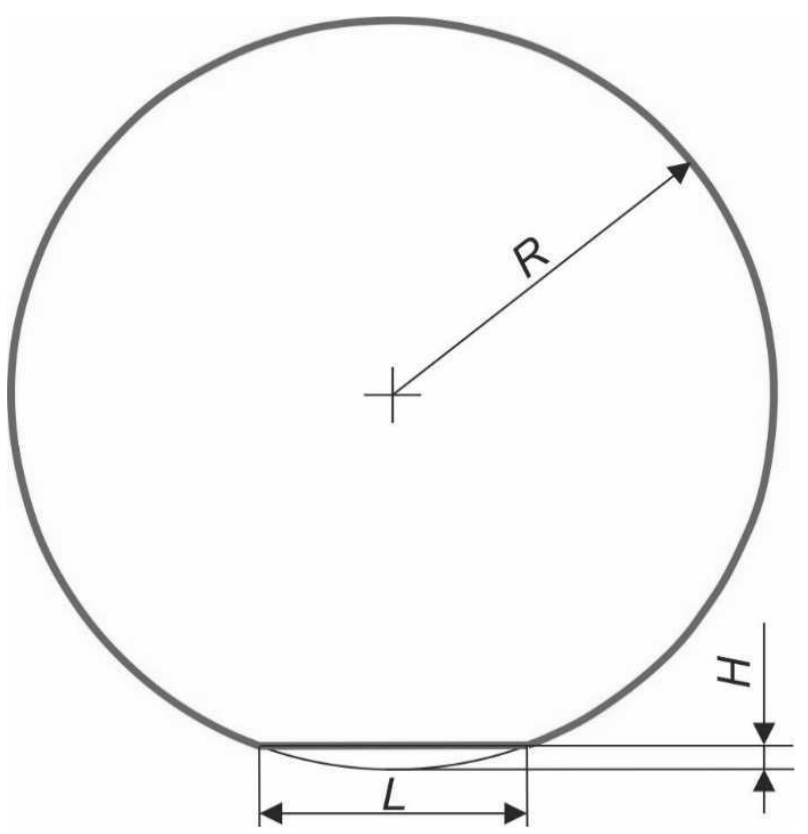

Fig. 5 Geometry of track model 
Tab. 1 Parameters of a wheel with a wheel flat

\begin{tabular}{|l|c|}
\hline Parameter & [mm] \\
\hline$R$ - wheel radius & 445 \\
\hline $\begin{array}{l}L-\text { Length of the wheel } \\
\text { flat }\end{array}$ & 20 \\
\hline$H-$ Wheel flat depth & 0.1123 \\
\hline
\end{tabular}

\section{Simulation results comparison}

For a better comparison of the results, we performed the simulation for the velocities of $30 \mathrm{~km} \cdot \mathrm{h}^{-1}, 60 \mathrm{~km} \cdot \mathrm{h}^{-1}$, $90 \mathrm{~km} \cdot \mathrm{h}^{-1}$ and $120 \mathrm{~km} \cdot \mathrm{h}^{-1}$. Since the wheel flat surface was simulated on the right wheel of the first wheelset of the front bogie, only the forces acting in the contact pair of that wheel were processed in the results.

The guiding forces acting in the transverse direction are shown in Fig. 6. From the graph we see that the lower the speed of the vehicle running along the track is, the higher the driving forces affecting the vehicle are.

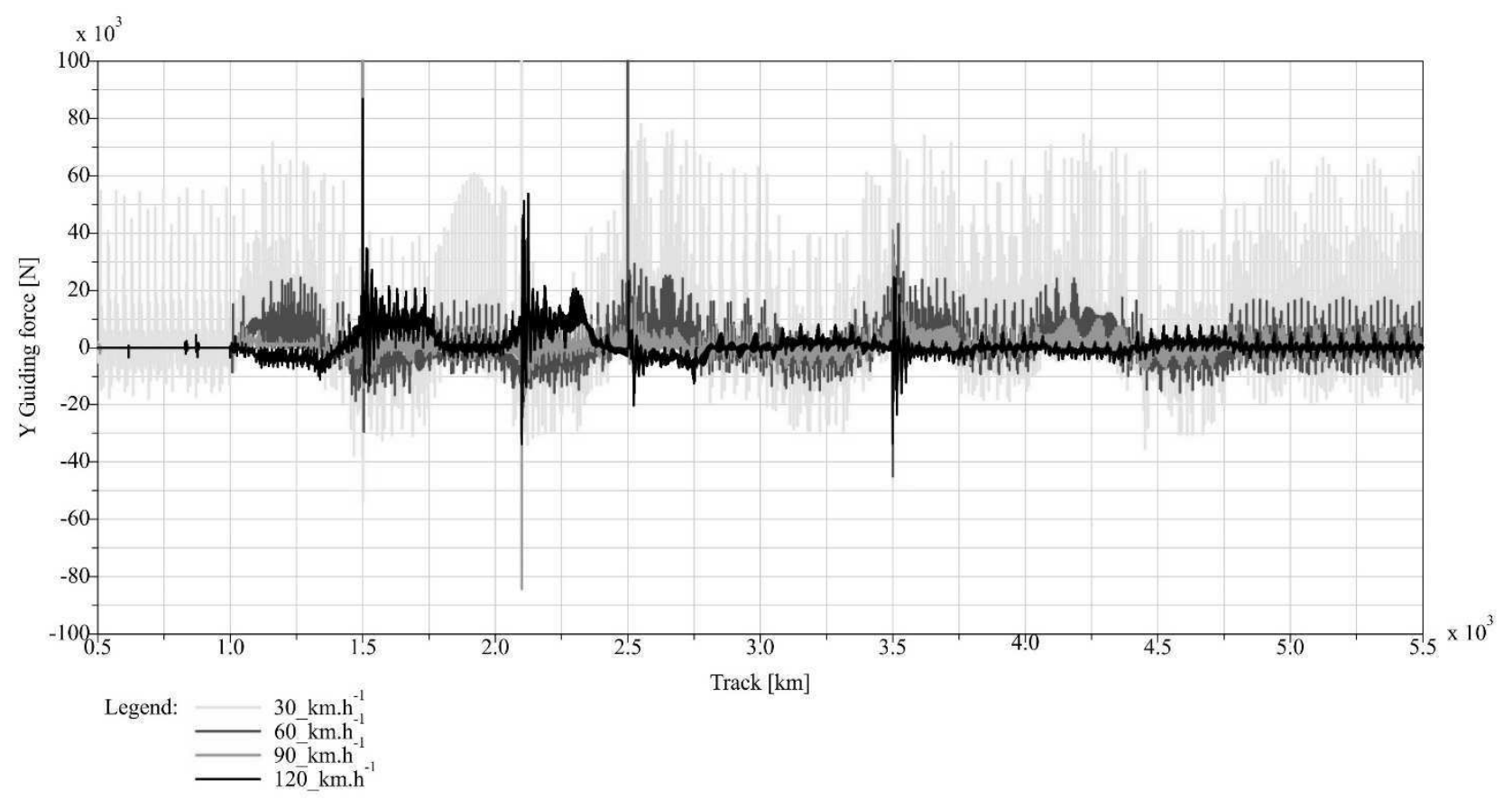

Fig. 6 Guiding forces acting on a front bogie wheel

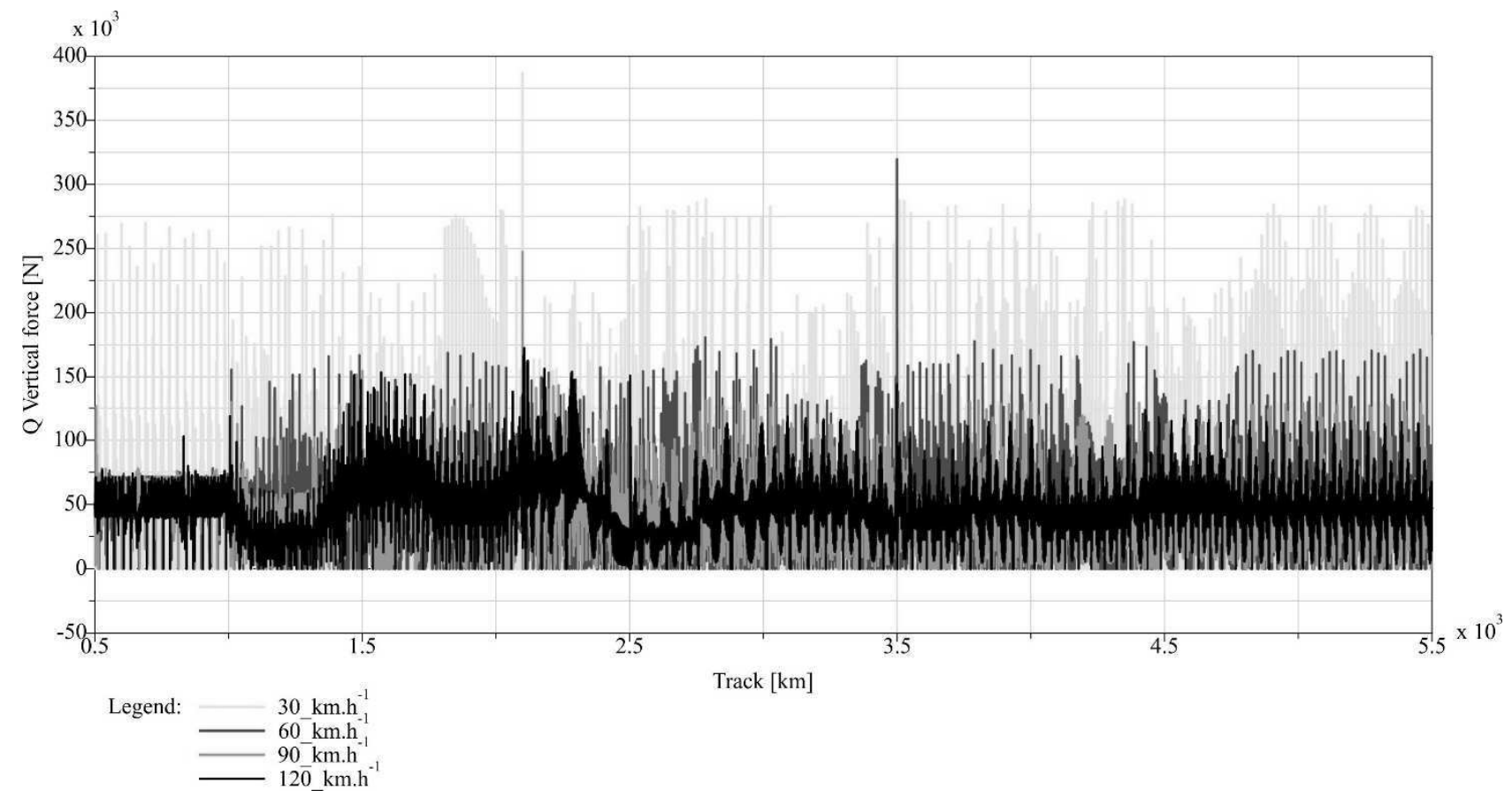

Fig. 7 Vertical wheel forces for all velocities 


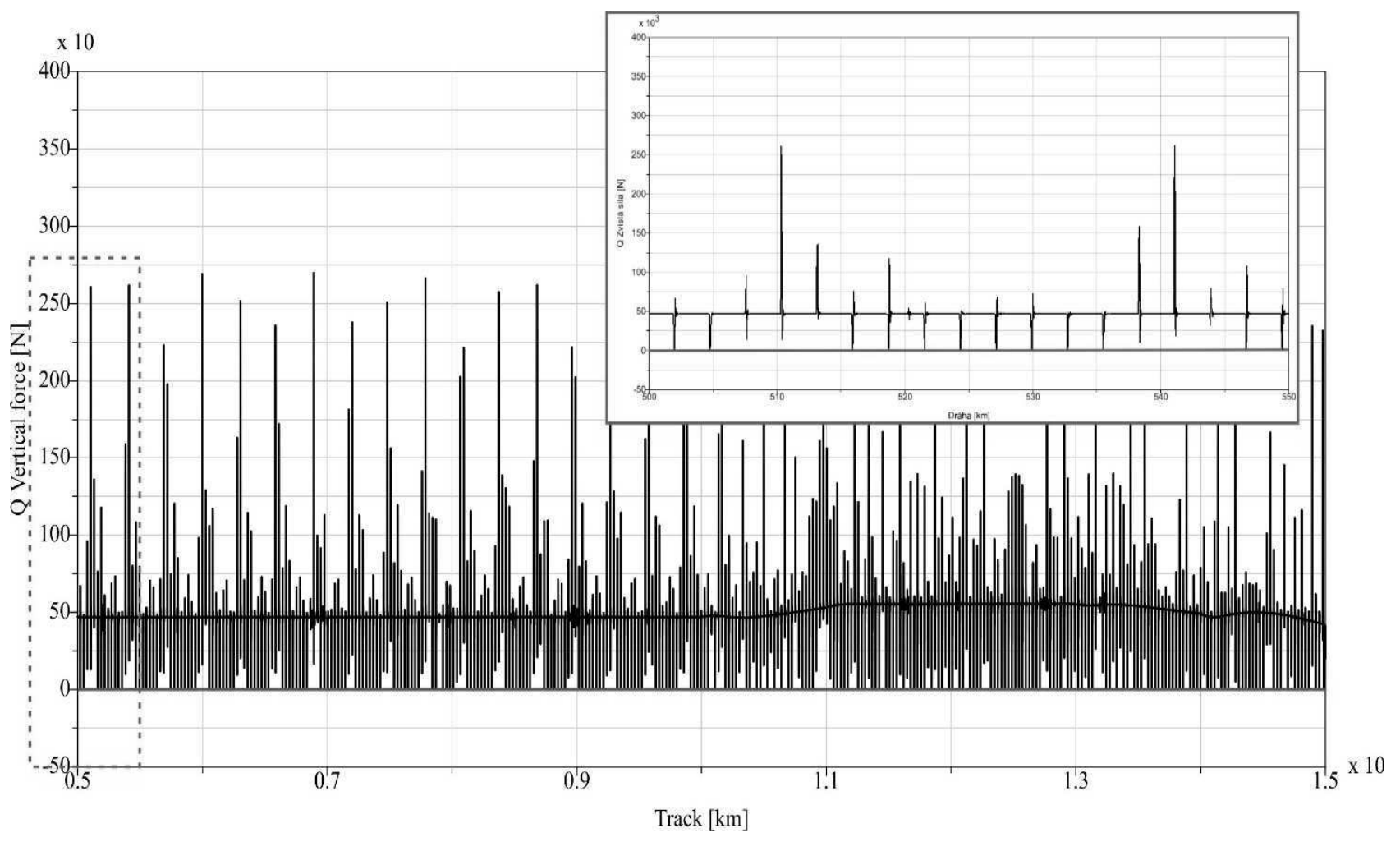

Fig. 8 Vertical wheel forces for the velocity $30 \mathrm{~km} \cdot \mathrm{h}^{-1}$

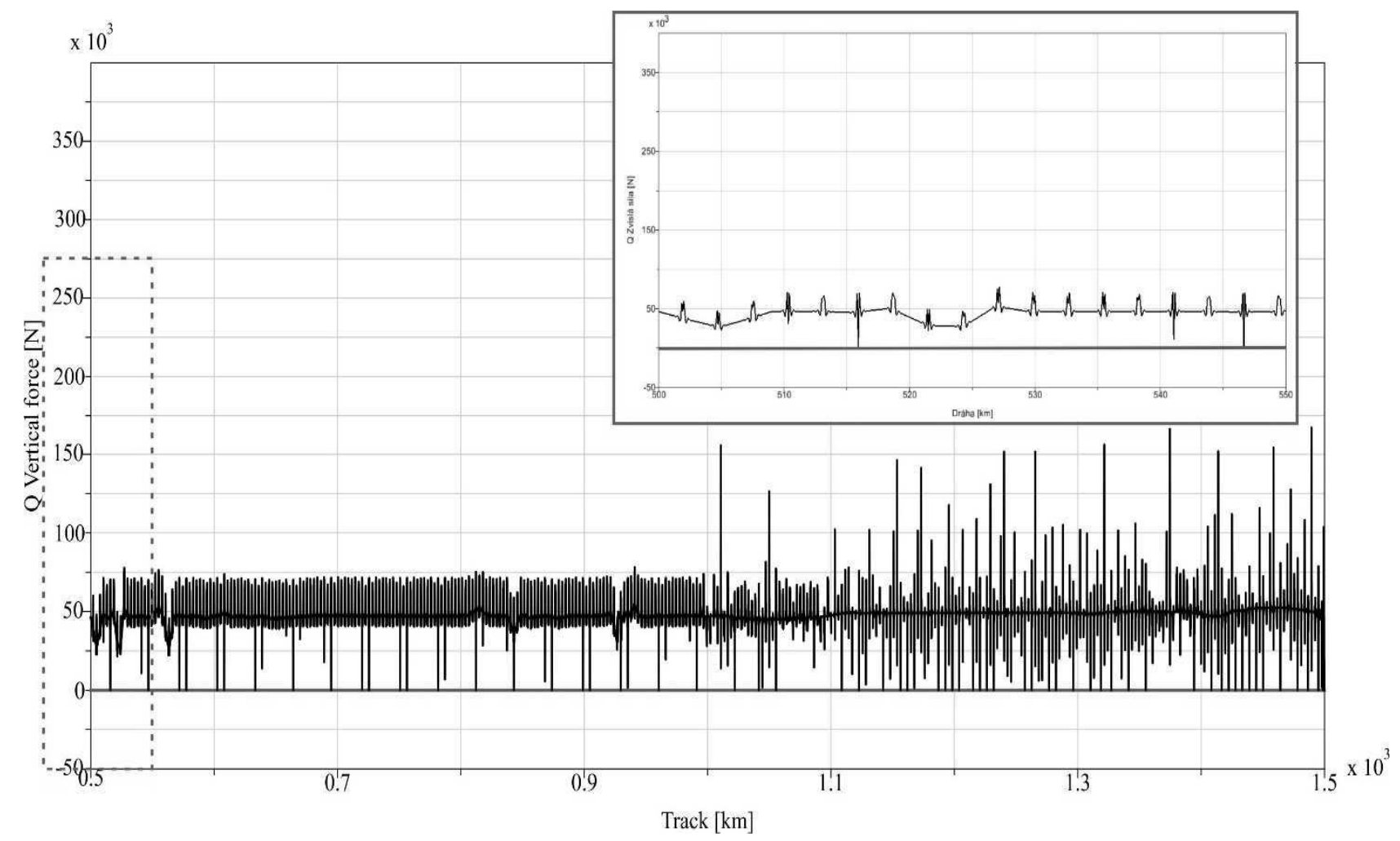

Fig. 9 Vertical wheel forces for the velocity $0 \mathrm{~km} \cdot \mathrm{h}^{-1}$ 


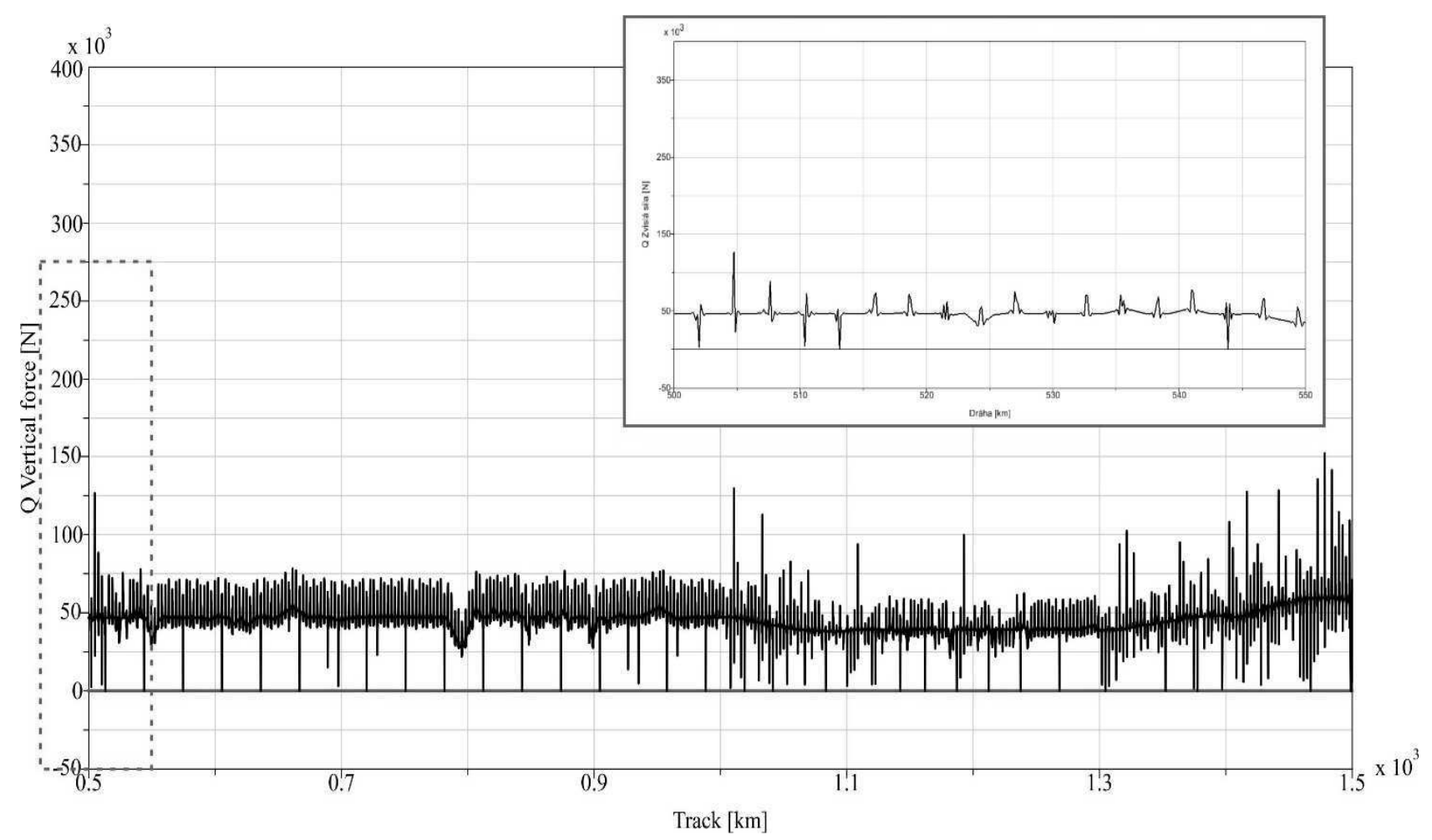

Fig. 10 Vertical wheel forces for the velocity $90 \mathrm{~km} . \mathrm{h}^{-1}$

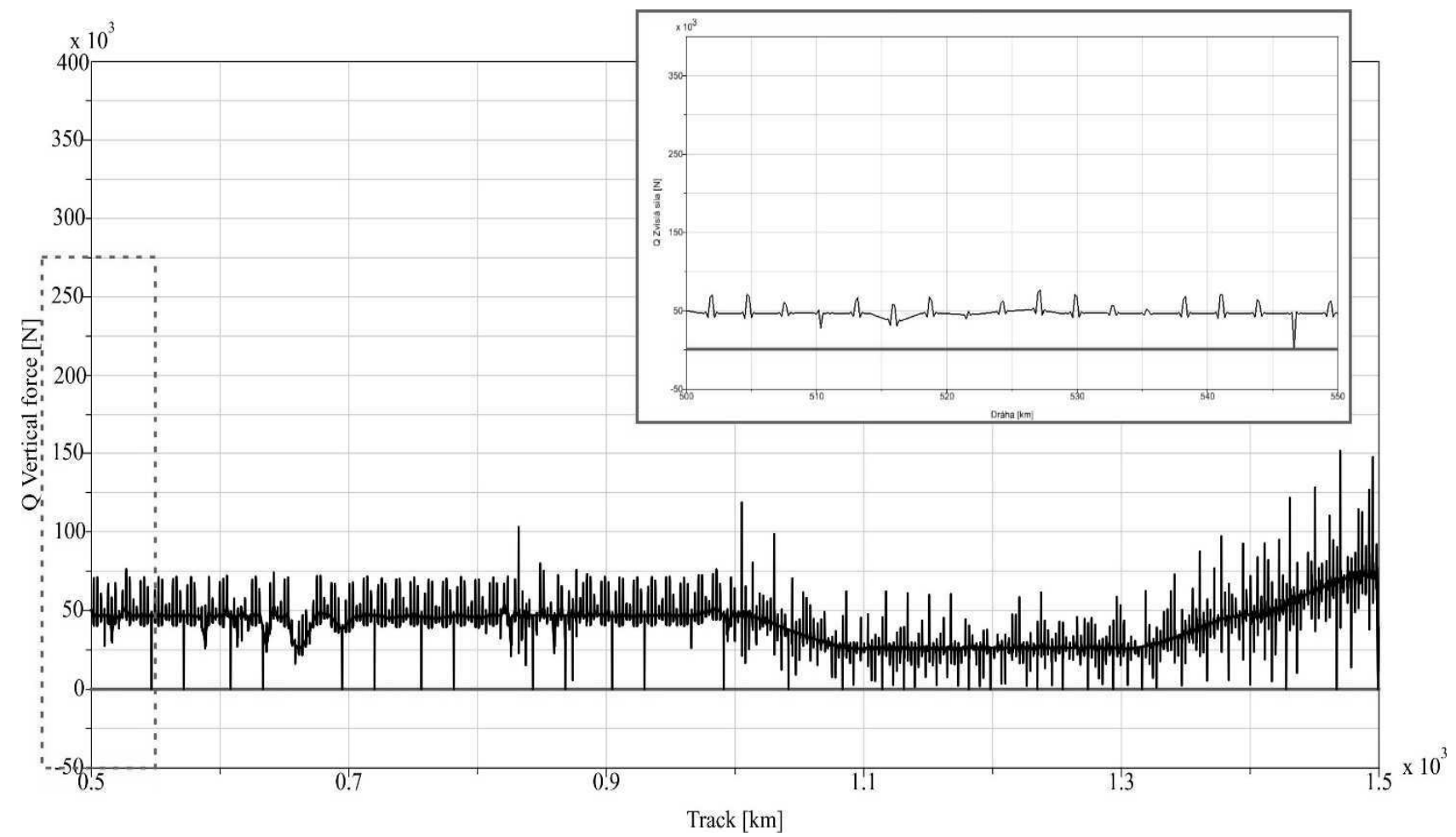

Fig. 11 Vertical wheel forces for the velocity $120 \mathrm{~km} \cdot \mathrm{h}^{-1}$

The expression of safety against derailment (Fig. 12) as a relative value equal to the ratio of the steering and wheel forces on the individual wheels in its course corresponds to the course of the driving forces. Higher values represent a worse state, lower values represent a safer ratio of horizontal forces to vertical forces. Even at the lowest speed, the vehicle did not exceed the known safety limit 0.8 . 


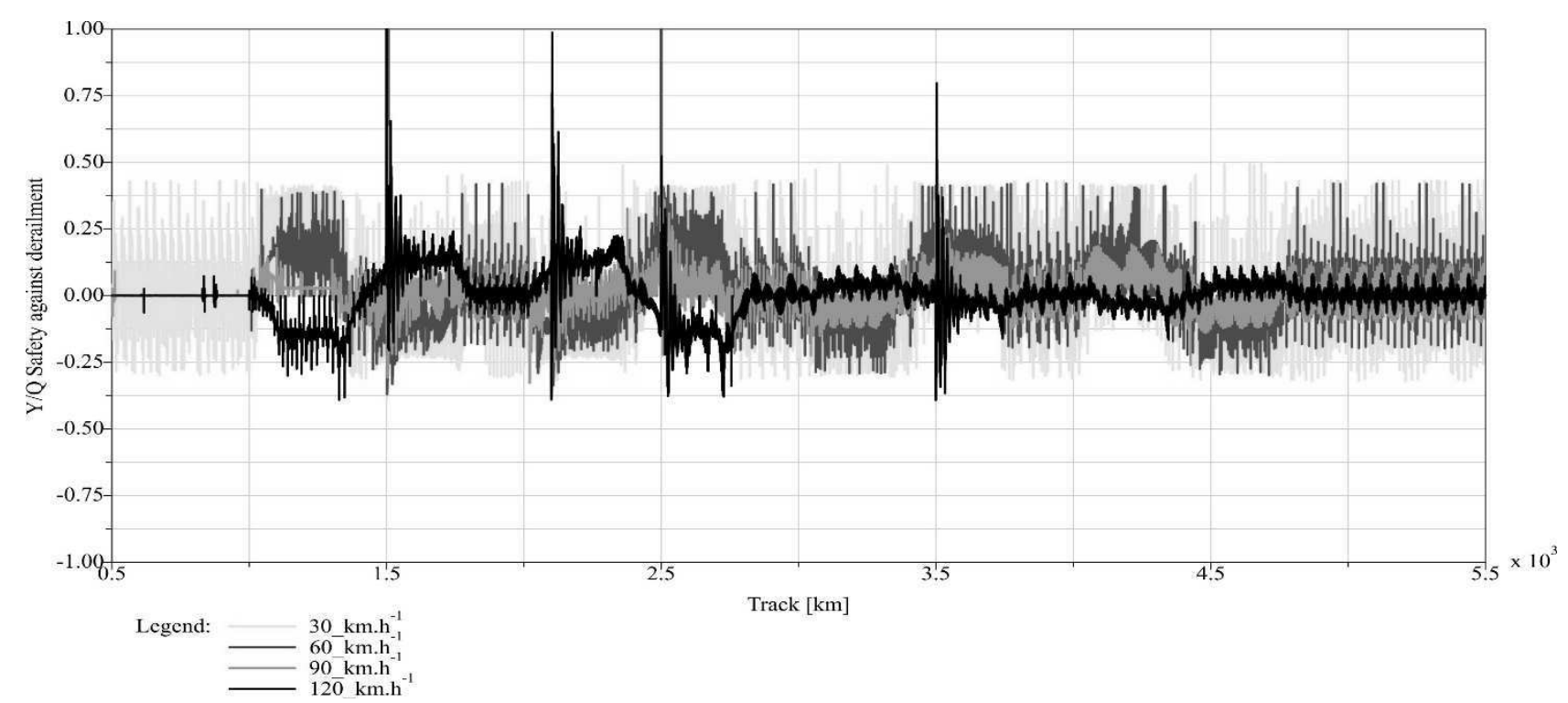

Fig. 12 Safety against derailment of the wheel with a wheel flat

\section{Conclusion}

In our article, we focused on simulating a ride of a rail vehicle that has a wheel flat on one of the wheels of the attacking wheelset. We compared the results for four driving speeds and compared the sizes of the guiding and vertical wheel forces and the safety against derailment values.

From the resulting graphs we can see that the wheel with a wheel flat reaches the worst results at the slowest speeds, when the highest guiding forces and the greatest difference in vertical wheel forces occur. Despite this fact, the safety against derailment value of the vehicle does not exceed the limit of 0.8 .

In the simulation, we considered an ideal track and a wheel flat on the right front wheel. We also plan to work with these results by adding and comparing them with results obtained by applying irregularity to the ideal track.

\section{Acknowledgement}

The work was supported by the Cultural and Educational Grant Agency of the Ministry of Education of the Slovak Republic in project No. KEGA 077ŽU-4/2017: Modernization of the Vehicles and engines study program. The work was also supported by the project No. APVV-0842-11: Equivalent railway operation load simulator on the roller rig and VEGA Nr. 1/0927/15: Research of the use of alternative fuels and hybrid drives on traction vehicles with aim to reduce fuel consumption and air pollutants production.

Research-Educational Center of Rail Vehicles (VVCKV)

\section{References}

[1] DIŽO, J., (2015). Analysis of a goods wagon running on a railway test track. In: Manufacturing technology: journal for science, research and production. ISSN 1213-2489. Vol. 16, no. 4 2016, s. 667-672.
[2] DIŽO, J., BLATNICKÝ, M., (2016). Computer analysis of the carriage running influence with wheel-flat on a track. In: Railway transport and logistics. ISSN 1336-7943. Roč. 12, č. 2 (2016). s. 15-19.

[3] DIŽO, J., STEIŠŪNAS S., BLATNICKÝ, M., (2016). Simulation analysis of the effects of a rail vehicle running with wheel flat. In: Manufacturing technology: journal for science, research and production. ISSN 1213-2489. Vol. 16, no. 5 2016, s. 889-896.

[4] DIŽO, J., BLATNICKÝ, M., (2015). Use of multibody system dynamics as a tool for rail vehicle behaviour diagnostics. In: Diagnostyka. - ISSN 1641-6414. - Vol 17, no. 2 (2016). s. 9-16.

[5] DIŽO, J., BLATNICKÝ, M., SKOČILASOVÁ, B., (2015). Computational modelling of the rail vehicle multibody system including flexible bodies. In: Communications: scientific letters of the University of Žilina. ISSN 1335-4205. Vol. 17, no. 32015 , s. 31-36.

[6] GAllikOVÁ, J., POPROCKÝ, R., VOLNA, P., (2016). Implementation of FMEA method in maintenance of semi-trailer combination. In: Manufacturing technology: journal for science, research and production. ISSN 1213-2489. Vol. 17, no. 4 2016, s. 85-92.

[7] GERLICI, J., GORBUNOV, M., KRAVCHENKO, K., KOSTYUCHEVICH, A., NOZHENKO, O., LACKT, T., (2008). Experimental rigs for wheel / rail contact research. In: Manufacturing technology: journal for science, research and production. ISSN 1213-2489. Vol. 16, no. 5 2016, pp. 909-916.

[8] GERLICI, J., GORBUNOV, M., KRAVCHENKO, K., DOMIN, R., 
KOVTANETS, M., LACK, T., (2017). Slipping and skidding occurrence probability decreasing by means of the friction controlling in the wheelbraking pad and wheel-rail contacts. In. Manufacturing technology: journal for science, research and production. ISSN 1213-2489. Vol. 17, no. 2 2017, pp. 179-186.

[9] GERLICI, J., LACK, T., (2009). Railway wheel profile development based on the geometric characteristics shapes. In: Contact mechanics and wear of rail/wheel systems = CM2009: 8th international conference: 15th-18th September 2009, Firenze, Italy. 2009. ISBN 978-88-904370-0-7, pp. 961-967.

[10] GERLICI, J., LACK, T., (2003). Rail geometry analysis (from the point of view of wearing in the operation). In: Communications - scientific letters of the University of Žilina. ISSN 1335-4205. Vol. 5, No. 1 (2003). (pp. 43-51).

[11] GERLICI, J., LACK, T., (2004). Contact railway wheelset and track. University of Žilina. ISBN 808070-317-5. (In Slovak)

[12] GERLICI, J., LACK, T., (2006). Synthesis of railway wheel and rail head profiles via the usage of arcs radii profile variation. In: Zeszyty naukowe Instytutu Pojazdów: mechanika, ekologia, bezpieczeństwo. ISSN 1642-347X. 1 (60)/2006, pp. 61-78.

[13] GERLICI, J., LACK, T., (2011). Railway wheel and rail head profiles development based on the geometric characteristics shapes. In: Wear: An international journal on the science and technology of friction, lubrication and wear. ISSN 0043-1648. Vol. 271, No. 1-2 Sp. iss. 2011, s. 246-258.

[14] GERLICI, J., LACK, T., (2010). Contact geometry influence on the rail / wheel surface stress distribution. In: Procedia Engineering. ISSN $1877-$ 7058. Iss. 1 2010, pp. 2249-2257.

[15] GERLICI, J., LACK, T., LACKOVÁ, M., (2004). Calculation of the equivalent conicity function of the railway wheelset tread profile at the Delta $R$ function with a negative slope. In: Communications - scientific letters of the University of Žilina. ISSN 1335-4205. Vol. 6, Nr. 2 2004, pp. 49-56

[16] HAUSER, V., (2015). Rail-wheel contact of tramways vehicles in arc track. In: TRANSCOM 2015: 11-th European conference of young researchers and scientists: Žilina, 2015. ISBN 978-80554-1048-7. S. 64-69.
[17] HAUSER, V., (2015). The analysis of passing tramway wheelset in the tracks with a small radius. In: Dynamics of rigid and deformable bodies 2015: Ústí nad Labem, FVTM UJEP, 2015. ISBN 978-80-7414-914-6.

[18] LACK, T., GERLICI, J., (2008). Analysis of vehicles dynamic properties from: The point of view of passenger comfort. In: Communications: scientific letters of the University of Žilina. ISSN 13354205. Vol. 16, no. 3A 2008, s. 10-18.

[19] LACK, T., GERLICI, J., (2009). Railway wheel and rail roughness analysis. In: Communications: Scientific Letters of the University of Žilina. ISSN 1335-4205. Vol. 11, No. 2 2009, pp. 41-48.

[20] LACK, T., GERLICI, J., (2014). Wheel/rail tangential contact stress evaluation by means of the modified strip method. In: Communications: scientific letters of the University of Žilina. ISSN 1335-4205. Vol. 16, no. 3A 2014, s. 33-39.

[21] LACK, T., GERLICI, J., (2016). Tangential stresses for non-elliptical contact patches computed by means of a modified FASTSIM method. In: CivilComp Proceedings. ISSN 1339-4509. Iss. 12016 , online, [10] s.

[22] LACK, T., GERLICI, J., (2013). Tangential stresses for non-elliptical contact patch computation by means of modified FASTIM method. In: IAVSD 2013: 23rd international symposium on dynamics of vehicles on roads and tracks: 19.-23. August 2013, Qingdao, China: proceedings. (p.6).

[23] LACK, T., GERLICI, J., (2013). The FASTSIM method modification in speed up the calculation of tangential contact stresses between wheel and rail. In: Manufacturing technology: journal for science, research and production. ISSN 12132489. Vol. 13, no. 4 2013, pp. 486-492.

[24] LACK, T., GERLICI, J., (2008). Interational method for railway wheel tread profile design. In: XVIII konferencja naukova - pojazdy szynowe: Katowice-Ustroń, 2008: Materialy konferencyjne, pp. 137-149.

[25] MAŇUROVÁ, M., (2014). Analysis of the driving characteristics of a rail vehicle using calculations. In: Experimental and computational methods in engineering- proceeding. 11. - 13. jun 2014, Ústí nad Labem, ISBN 978-80-7414-725-8. CD-ROM, [10] s. (In Slovak)

[26] SIMPACK A.G., (2014). Documentation to the program system SIMPACK. 